\title{
Prevalence of antibiotic resistance in lactic acid bacteria isolated from the faeces of broiler chicken in Malaysia
}

\author{
Nurhazirah Shazali ${ }^{1}$, Hooi Ling Foo $2,4^{*}$, Teck Chwen Loh ${ }^{1,5}$, Di Wei Choe ${ }^{1}$ and Raha Abdul Rahim,
}

\begin{abstract}
Background: Probiotics are commonly used as feed additive to substitute antibiotic as growth promoter in animal farming. Probiotic consists of lactic acid bacteria $(\mathrm{LAB})$, which enhance the growth and health of the animal. Probiotic also have higher possibility to become pathogenic bacteria that may carry antibiotic resistant gene that can be transmitted to other $L A B$ species. The aim of this study was to identify the $L A B$ species in the faeces of broiler chicken and to determine the prevalence of antibiotic resistant in $\angle A B$ of broiler chicken.
\end{abstract}

Methods: Sixty faeces samples were collected from wet markets located in Klang Valley of Malaysia for the isolation of $\angle A B$ using de-Mann Rogosa Sharpe medium. Thirteen species of $L A B$ were obtained in this study and the identification of $L A B$ was performed by using API test kit on the basis of carbohydrate fermentation profile. Antibiotic susceptibility assay was then carried out to determine the prevalence of $\angle A B$ antibiotic resistance.

Results: Lactococcus lactis subsp lactis was found in nine out of sixty faecal samples. Lactobacillus paracasei was the second common $L A B$ species isolated from chicken faecal. No significant difference $(P>0.05)$ was found between the occurrence of Lactobacillus brevis, Lactobacillus curvatus, Lactobacillus plantarum, Leuconostoc lactis mesenteroides subsp mesenteroides/dectranium and Pediococcus pentosaceus isolated from 5 different locations. Most of the isolated LAB was resistant to antibiotic and high variability of the antibiotic resistance was observed among the LAB against 15 types of antibiotics. Penicillin, amoxicillin, chloramphenicol, and ampicillin had significant higher $(P<0.05)$ inhibitory zone than nalidixic acid, gentamycin, sulphamethoxazole, kanamycin, and streptomycin.

Conclusions: Many species of $L A B$ were isolated from the faecal samples of broiler chicken that resistance to the common antibiotics used in the farm. The development of resistant against antibiotics in $L A B$ can be attributed to the long term exposure of antibiotic as growth promoter and therapeutic agents. Thus, it is essential to advise farmer the safety measure of antibiotic application in animal farming. Additionally, the supplementation of probiotic in animal feeding also needs more attention and close monitoring.

Keywords: Lactic acid bacteria, Antibiotic resistance, Broiler chicken

\section{Background}

Antibiotic are normally used to treat microbial diseases since 50 years ago. However, excessive use of antibiotic may lead to the development of antibiotic resistance in pathogenic bacteria. The report of antibiotic resistance is

\footnotetext{
* Correspondence: hlfoo@upm.edu.my

${ }^{2}$ Department of Bioprocess Technology, Faculty of Biotechnology and Biomolecular Sciences, Universiti Putra Malaysia, 43400, UPM Serdang Selangor, Malaysia

${ }^{4}$ Institute of Bioscience, Universiti Putra Malaysia, 43400, UPM Serdang

Selangor, Malaysia

Full list of author information is available at the end of the article
}

significantly increased due to the overuse and misuse of antibiotics, which has created an enormous selective pressure on the recessive bacteria [1]. Antibiotic resistant bacteria have the ability to resist toward the actions of naturally occurring or synthetically produced compounds inimical to their survival [2].

Scott [3] reported the identical resistance gene present in bacterial species isolated from different hosts. Antibiotic resistant may acquires through the in-vivo gene transfer between normal flora of gastrointestinal and antibiotic resistant pathogenic bacteria [4]. In fact, the antibiotic resistant pathogenic bacteria pose a great potential 
threat to human health, especially when the immunity system is not functioning well. Most of the developed countries have prohibited the use of antibiotic as animal growth promoter. Thus, various alternatives have been explored to replace antibiotic as growth promoter. One of the most common and popular alternatives is the application of probiotic as growth promoter in livestock animals. In addition, the probiotic effects of postbiotic metabolites produced by probiotic strains have been shown in various animal species, such as rats $[5,6]$, broilers $[7,8]$, laying hens [9] and post weaning piglets [10], suggesting they have great potential to be used as growth promoter for livestock animals.

Probiotic comprises of beneficial bacteria such as lactic acid bacteria (LAB). LAB is a group of gram-positive anaerobic bacteria which produce predominantly lactic acid from carbohydrate fermentation. Many farmers use probiotic extensively and those bacteria have potential to serve as a host of antibiotic resistance genes with a risk of transferring those genes into many LAB and other pathogens [11].

The antibiotic resistant LAB has been detected by using DNA sequences which is responsible for antibiotic resistance traits. Egervärn et al. [12] reported the emergence of antibiotic resistant in Lactobacillus reuteri and Lactobacillus plantarum. Moreover, Lactobacilli, Pediococci and Leuconostoc spp. have been reported to be highly resistant to vancomycin $[11,13]$ and some Lactobacilli have high resistance to bacitracin, cefoxitin, ciprofloxacin, fusidic acid, streptomycin, sulphadiazine, teicoplanin and vancomycin [14]. Most of the reported LAB that resistant to antibiotics was isolated from food sources. These include the most commonly used probiotic species such as Lactobacillus casei, Lactobacillus acidophilus, L. reuteri, or Lactobacillus rhamnosus, among others, or the yogurt starter bacteria Lactobacillus delbrueckii [15-17]. However, the information of antibiotic resistant LAB isolated from the gut of broiler chickens in Malaysia is very limited. Thus, the objective of this study was to investigate the antibiotic resistance profile of LAB isolated from the gut of broiler chickens in Klang Valley, Malaysia.

\section{Materials and methods}

\section{Sample origin and collection}

A total of 60 faeces samples were collected from chicken purchased from wet markets located nearby Universiti Putra Malaysia: Serdang Jaya, Seri Kembangan, Dengkil, Putrajaya, Kajang, Pantai Dalam, and Jenderam Hilir. The age of the chicken was 42 days. The faeces were collected directly from caeca junction to the end of the cloaca of large intestine. The faeces samples (1 g each) were kept at $-20^{\circ} \mathrm{C}$ until further analysis. The experimental design has obtained approval from the Ethics Committee of Universiti Putra Malaysia.

\section{Enumeration and isolation of lactic acid bacteria}

The faeces sample was mixed homogeneously at a ratio of $1 \mathrm{~g}$ sample with $9 \mathrm{ml}$ of peptone water in the universal bottle and incubated for one hour at room temperature. The samples were then subjected to 10 -fold serial dilution using $0.1 \%(\mathrm{v} / \mathrm{v})$ peptone water [18] and $0.1 \mathrm{ml}$ of each appropriate diluted sample was then plated onto de Man Rogosa Sharpe (MRS) agar and incubated under anaerobic condition at $30^{\circ} \mathrm{C}$ for 48 hours [19]. The colony forming unit (CFU) per gram of sample was expressed as logarithm at the base of $10\left(\log _{10} \mathrm{CFU} / \mathrm{g}\right)$. The enumeration of LAB was conducted in triplicates. After 48 hours of incubation, a colony was picked and streaked onto MRS agar and incubated for additional $48 \mathrm{~h}$ at $30^{\circ} \mathrm{C}$. This process was repeated twice and a pure colony was then transferred to MRS broth and incubated at $30^{\circ} \mathrm{C}$ for $24 \mathrm{~h}$. The pure LAB culture was then kept in MRS broth supplemented with $20 \%$ (v/v) glycerol and incubated at $-20^{\circ} \mathrm{C}$ until further analysis.

\section{Identification of lactic acid bacteria}

LAB culture was identified phenotypically on the basis of carbohydrate fermentation profile by using API $50 \mathrm{CH}$ kit (BioMerieux, France) according to the instruction of manufacturer. The carbohydrate fermentation profile was then analysed by using APILAB Plus software version 3.3.3 (BioMerieux, France) to identify the species of each isolated LAB culture.

\section{Antibiotic susceptibility assay}

The antibiotics used for susceptibility assay were ampicillin $(10 \mu \mathrm{g})$, clindamycin $(2 \mu \mathrm{g})$, erythromycin $(15 \mu \mathrm{g})$, gentamicin $(10 \mu \mathrm{g})$, streptomycin $(25 \mu \mathrm{g})$, tetracycline $(30 \mu \mathrm{g})$, chloramphenicol $(30 \mu \mathrm{g})$, kanamycin $(30 \mu \mathrm{g})$, sulphamethoxazole/trimethoprim $(25 \mu \mathrm{g})$, vancomycin $(30 \mu \mathrm{g})$, ciprofloxacin $(5 \mu \mathrm{g})$, amoxicillin $(10 \mu \mathrm{g})$, bacitracin $(10 \mu \mathrm{g})$, nalidixic acid $(30 \mu \mathrm{g})$, and penicillin $(10 \mu \mathrm{g})$ (Oxoid Ltd, England). The antibiotics were selected due to their common use in local animal farming. A total of $1 \mathrm{ml} \mathrm{LAB} \mathrm{cul-}$ ture grown in MRS broth was collected by centrifugation at $1000 \times \mathrm{g}$ for $5 \mathrm{~min}$. The cell pellet was collected and washed twice using $1 \mathrm{ml}$ of $0.85 \%$ (w/v) $\mathrm{NaCl}$, followed by suspending the cell pellet with $0.5 \mathrm{ml}$ of $0.85 \%$ (w/v) $\mathrm{NaCl}$. The cell suspension was adjusted to $0.5 \mathrm{Mc}$ Farland by using $2 \mathrm{ml}$ of $\mathrm{NaCl} 0.85 \%(\mathrm{w} / \mathrm{v})$ prior to spread plate on MRS agar. The antibiotic disc was then placed on MRS agar plate. The diameter of inhibitory zones was measured after $48 \mathrm{~h}$ of incubation at $30^{\circ} \mathrm{C}$ under anaerobic condition. The assay was conducted in triplicates [20].

\section{Statistical analysis}

The data was analysed using one way analysis of variance (ANOVA) with probability level of $0.05(\mathrm{P}<0.05)$ using SAS statistical software [21]. 
Table 1 Lactic acid bacteria species isolated from faecal samples collected from various locations

\begin{tabular}{|c|c|c|c|c|c|c|c|c|c|c|c|c|c|}
\hline Locations & $\begin{array}{c}\text { L. } \\
\text { acidophilus }\end{array}$ & $\begin{array}{c}\text { L. } \\
\text { brevis }\end{array}$ & $\begin{array}{c}\text { L. } \\
\text { curvatus }\end{array}$ & $\begin{array}{l}\text { L. delbrueckii } \\
\text { subsp } \\
\text { delbrueckii }\end{array}$ & $\begin{array}{c}L . \\
\text { fermentum }\end{array}$ & $\begin{array}{l}\text { L. paracasei } \\
\text { subsp } \\
\text { paracasei }\end{array}$ & $\begin{array}{c}L . \\
\text { plantarum }\end{array}$ & $\begin{array}{l}\text { L. rhamnosus } \\
\text { (L. casei subsp } \\
\text { rhamnosus) }\end{array}$ & $\begin{array}{c}\text { L. } \\
\text { salivarius }\end{array}$ & $\begin{array}{l}\text { Lc. lactis } \\
\text { subsp } \\
\text { lactis }\end{array}$ & $\begin{array}{c}\text { Leu. lactis } \\
\text { mesenteroides } \\
\text { subsp } \\
\text { mesenteroides/ } \\
\text { dextranicum }\end{array}$ & $\begin{array}{c}P . \\
\text { damnosus }\end{array}$ & $\begin{array}{c}P . \\
\text { pentosaceus }\end{array}$ \\
\hline Dengkil 1 & 0 & 0 & 1 & 0 & 0 & 3 & 0 & 0 & 0 & 1 & 0 & 0 & 1 \\
\hline Dengkil 2 & 0 & 0 & 2 & 0 & 0 & 0 & 0 & 1 & 0 & 1 & 0 & 2 & 0 \\
\hline Jenderam Hilir & 0 & 0 & 1 & 3 & 0 & 0 & 0 & 0 & 0 & 1 & 0 & 0 & 1 \\
\hline Kajang & 0 & 2 & 0 & 0 & 0 & 0 & 0 & 0 & 0 & 2 & 2 & 0 & 0 \\
\hline Serdang Jaya 1 & 0 & 0 & 1 & 0 & 0 & 0 & 1 & 0 & 0 & 2 & 0 & 2 & 0 \\
\hline Serdang Jaya 2 & 0 & 2 & 0 & 2 & 1 & 1 & 0 & 0 & 0 & 0 & 0 & 0 & 0 \\
\hline Seri Kembangan & 1 & 0 & 0 & 1 & 0 & 3 & 0 & 1 & 0 & 0 & 0 & 0 & 0 \\
\hline Pantai Dalam & 0 & 0 & 0 & 0 & 1 & 0 & 1 & 0 & 2 & 0 & 2 & 0 & 0 \\
\hline Putrajaya & 0 & 1 & 0 & 0 & 0 & 0 & 2 & 0 & 1 & 2 & 0 & 0 & 0 \\
\hline UPM & 0 & 0 & 0 & 0 & 0 & 0 & 1 & 0 & 1 & 0 & 1 & 0 & 3 \\
\hline Total & 1 & 5 & 5 & 6 & 2 & 7 & 5 & 2 & 4 & 9 & 5 & 4 & 5 \\
\hline
\end{tabular}

Note: A total of 6 samples were collected from each location. 


\section{Results and discussion}

\section{Identification of lactic acid bacteria}

All LAB species isolated from faeces of broiler chicken were identified by API Kit. Table 1 shows the identity of LAB species isolated from various wet markets located in Klang Valley of Malaysia. The result demonstrated that different LAB species were isolated from different wet market and the most common LAB species isolated from chicken faecal was Lactococcus lactis subsp lactis as it was isolated from 9 out of 60 samples. Lactobacillus paracase $i$ was the second common LAB species isolated from chicken faecal. However, there was no significant different $(\mathrm{P}>0.05)$ between the occurrence of Lactobacillus brevis, Lactobacillus curvatus, Lactobacillus plantarum, Leuconostoc lactis mesenteroides subsp mesenteroides/dectranium and Pediococcus pentosaceus as they were isolated from 5 different locations. Pediococcus damnosus was isolated from 4 locations, whereas Lactobacillus fermentum and L. rhamnosus (Lactobacillus casei subsp rhamnosus) were isolated from 2 locations.

It has been reported that L. acidophilus and Lactobacillus salivarius have higher chance to be isolated among the Lactobacillus strains colonizing in the crop intestine [22]. However, L. acidophilus and L. salivarius were only found in faeces samples 1 and 4, respectively; indicating L. acidophilus and L. salivarius were not a common $\mathrm{LAB}$ found in the faeces of chicken sold in Klang valley of Malaysia.

\section{Antibiotic resistance of lactic acid bacteria}

Table 2 shows the inhibitory zone of antibiotic susceptibility for nine LAB regardless of species obtained from faecal samples. Penicillin, amoxicillin, chloramphenicol, and ampicillin had significant higher $(\mathrm{P}<0.05)$ inhibitory zone than nalidixic acid, gentamycin, sulphamethoxazole, kanamycin, and streptomycin. These results were similar with the previous report, where lactobacilli were most sensitive to penicillin and ampicillin except for amoxicillin and chloramphenicol [23]. However, there was no significantly different $(\mathrm{P}>0.05)$ between vancomycin and bacitracin. Similar inhibitory zone was also found in bacitracin, nalidixic acid, gentamycin, sulphamethoxazole, kanamycin, and streptomycin. LAB was sensitive to clindamycin, chloramphenicol, amoxicillin, penicillin, erythromycin, and ampicillin in current study. However, it was resistant against nalidixic acid, bacitracin, gentamycin, ciprofloxacin, sulphamethoxazole, kanamycin, tetracycline, streptomycin and vancomycin. These results indicate that $\mathrm{LAB}$ is not sensitive to beta-lactams group of antibiotics due to the absence of peptidoglycan in LAB cell. However, Lavanya et al. [24] reported recently that most of the LAB isolated from fermented milk were resistant to penicillin $\mathrm{G}$ and only $10 \%$ were susceptible to ampicillin. Betalactams antibiotics were the most effective drugs for the
Table 2 Diameter inhibitory zone (Mean $\pm \mathrm{SE}$ ), $\mathrm{cm}$ of antibiotic susceptibility test for LAB regardless of species from chicken faecal sample

\begin{tabular}{lc}
\hline Antibiotics & Diameter of inhibitory zone (cm) \\
\hline Nalidixic acid & $0.02^{\mathrm{e}} \pm 0.02$ \\
Clindamycin & $1.22^{\mathrm{b}} \pm 0.16$ \\
Bacitracin & $0.33^{\mathrm{de}} \pm 0.07$ \\
Chloramphenicol & $1.89^{\mathrm{a}} \pm 0.17$ \\
Amoxycillin & $1.93^{\mathrm{a}} \pm 0.16$ \\
Gentamycin & $0.07^{\mathrm{e}} \pm 0.04$ \\
Ciprofloxacin & $0.21 \mathrm{~d}^{\mathrm{e}} \pm 0.06$ \\
Penicillin & $1.99^{\mathrm{a}} \pm 0.17$ \\
Sulphamethoxazole & $0.11^{\mathrm{e}} \pm 0.05$ \\
Kanamycin & $0.05^{\mathrm{e}} \pm 0.04$ \\
Tetracycline & $0.75^{\mathrm{c}} \pm 0.13$ \\
Erytromycin & $1.17^{\mathrm{b}} \pm 0.15$ \\
Ampicillin & $1.84^{\mathrm{a}} \pm 0.16$ \\
Streptomycin & $0.05^{\mathrm{e}} \pm 0.04$ \\
Vancomycin & $0.51^{\mathrm{cd}} \pm 0.12$ \\
\hline
\end{tabular}

Note: ${ }^{a-e}$ Means with different superscripts are significantly different $(P<0.05)$.

treatment of Staphylococci infections. However, Tyler et al., [25] reported that beta-lactams antibiotics have no longer effective to treat Staphylococcus aureus infections such as methicillin-resistant $S$. aureus and vancomycinresistant $S$. aureus.

The development of antibiotic resistance in LAB has revealed the fact that the common use of antibiotic as growth promoter in the farm has allowed LAB to develop resistance against antibiotics [26]. The antibiotic resistance in LAB may also acquire through horizontal transferring of resistance gene to the normal LAB by conjugative transposons [1]. As reported by Gilchrist et al. [26], antibiotic resistance in LAB was partly due to poor control of antibiotic as therapeutic and growth promoter in animal feeding. This may contribute to the build-up reservoir of antibiotic resistant bacteria in the gut. Hence, the current result suggests that antibiotic resistance screening is essential before any LAB strains are selected as feed additive for animal feeding.

\section{Profile of lactic acid bacteria antibiotic resistance}

Table 3 shows the diameter of inhibitory zone of antibiotic susceptibility among the LAB species. The inhibitory zone for Leu. lactis mesenteroides subsp mesenteroides/dextranicum was significantly higher $(\mathrm{P}<0.05)$ than other LAB species for the tested antibiotics. Bassam [27] reported that Leu. lactis mesenteroides was resistant to $100 \%$ vancomycin, $75 \%$ teicoplanin, $87.5 \%$ clindamycin, $75 \%$ chloramphenicol, erythromycin, gentamicin and streptomycin, 62.5\% ampicillin, penicillin $\mathrm{G}$ and tetracycline, $50 \%$ kanamycin and trimethoprim. L. acidophilus was 
Table 3 Diameter, $\mathrm{cm}$ (Mean \pm SE) of inhibitory zone of lactic acid bacteria species

\begin{tabular}{|c|c|c|c|c|c|c|c|}
\hline Lactic acid bacteria & Sulphamethoxazole & Kanamycin & Tetracycline & Erytromycin & Ampicillin & Streptomycin & Vancomycin \\
\hline L. acidophilus & $0.00^{\mathrm{a}} \pm 0.00$ & $0.00^{\mathrm{a}} \pm 0.00$ & $1.28^{\mathrm{a}} \pm 0.16$ & $1.22^{\mathrm{a}} \pm 0.16$ & $1.22^{\mathrm{a}} \pm 0.16$ & $0.00^{\mathrm{a}} \pm 0.00$ & $0.00^{\mathrm{a}} \pm 0.00$ \\
\hline L. brevis & $0.00^{c} \pm 0.00$ & $0.00^{c} \pm 0.00$ & $0.60^{\mathrm{abc}} \pm 0.08$ & $1.12^{\mathrm{abc}} \pm 0.15$ & $2.02^{\mathrm{ab}} \pm 0.26$ & $0.00^{c} \pm 0.00$ & $0.50^{b c} \pm 0.06$ \\
\hline L. curvatus & $0.00^{\mathrm{a}} \pm 0.00$ & $0.00^{\mathrm{a}} \pm 0.00$ & $0.00^{\mathrm{a}} \pm 0.00$ & $0.60^{\mathrm{a}} \pm 0.08$ & $1.40^{\mathrm{a}} \pm 0.18$ & $0.00^{\mathrm{a}} \pm 0.00$ & $0.52^{\mathrm{a}} \pm 0.07$ \\
\hline L. delbrueckii subsp delbrueckii & $19.75^{\mathrm{a}} \pm 2.54$ & $22.00^{\mathrm{a}} \pm 2.84$ & $24.25^{\mathrm{a}} \pm 3.13$ & $26.50^{\mathrm{a}} \pm 3.42$ & $29.30^{\mathrm{a}} \pm 3.78$ & $31.00^{\mathrm{a}} \pm 4.00$ & $33.78^{\mathrm{a}} \pm 4.36$ \\
\hline L. fermentum & $2.25^{\mathrm{a}} \pm 0.29$ & $2.50^{\mathrm{a}} \pm 0.03$ & $3.08^{a} \pm 39$ & $3.62^{\mathrm{a}} \pm 0.47$ & $4.68^{\mathrm{a}} \pm 0.60$ & $3.50^{\mathrm{a}} \pm 0.45$ & $4.40^{\mathrm{a}} \pm 0.57$ \\
\hline L. paracasei subsp paracasei & $0.00^{9} \pm 0.00$ & $0.28^{\mathrm{fg}} \pm 0.04$ & $1.30^{\text {cdef }} \pm 0.17$ & $1.88^{\mathrm{abcd}} \pm 0.24$ & $2.60^{\mathrm{ab}} \pm 0.34$ & $0.22^{\mathrm{fg}} \pm 0.03$ & $1.00^{\text {defg }} \pm 0.13$ \\
\hline L. plantarum & $0.00^{f} \pm 0.00$ & $0.00^{f} \pm 0.00$ & $1.80^{\mathrm{abcd}} \pm 0.23$ & $1.58^{\mathrm{abcd}} \pm 0.20$ & $2.50^{\mathrm{ab}} \pm 0.32$ & $0.00^{f} \pm 0.00$ & $1.15^{\text {cdef }} \pm 0.15$ \\
\hline L. rhamnosus (L. casei subsp rhamnosus) & $20.00^{\mathrm{a}} \pm 2.58$ & $22.25^{\mathrm{a}} \pm 2.87$ & $25.15^{\mathrm{a}} \pm 3.25$ & $27.38^{\mathrm{a}} \pm 3.53$ & $30.02^{\mathrm{a}} \pm 3.88$ & $31.25^{\mathrm{a}} \pm 4.03$ & $33.50^{\mathrm{a}} \pm 4.33$ \\
\hline L. salivarius & $2.25^{\mathrm{a}} \pm 0.29$ & $3.00^{\mathrm{a}} \pm 0.39$ & $2.75^{\mathrm{a}} \pm 0.36$ & $3.45^{\mathrm{a}} \pm 0.45$ & $4.22^{\mathrm{a}} \pm 0.55$ & $3.50^{\mathrm{a}} \pm 0.45$ & $4.25^{\mathrm{a}} \pm 0.55$ \\
\hline Lc. Lactis subsp lactis & $0.25^{b} \pm 0.03$ & $0.00^{b} \pm 0.00$ & $0.78^{\mathrm{b}} \pm 0.10$ & $1.92^{\mathrm{a}} \pm 0.25$ & $2.35^{\mathrm{a}} \pm 0.30$ & $0.00^{\mathrm{b}} \pm 0.00$ & $0.48^{\mathrm{b}} \pm 0.06$ \\
\hline Leu. lactis mesenteroides subsp mesenteroides/dextranicum & $39.5^{\mathrm{a}} \pm 5.10$ & $44.00^{\mathrm{a}} \pm 5.68$ & $48.50^{\mathrm{a}} \pm 6.26$ & $53.65^{\mathrm{a}} \pm 6.93$ & $57.90^{\mathrm{a}} \pm 7.48$ & $62.00^{\mathrm{a}} \pm 8.01$ & $66.50^{\mathrm{a}} \pm 8.59$ \\
\hline P. damnosus & $4.50^{\mathrm{a}} \pm 0.58$ & $5.00^{\mathrm{a}} \pm 0.65$ & $5.88^{\mathrm{a}} \pm 0.76$ & $6.55^{\mathrm{a}} \pm 0.85$ & $6.90^{\mathrm{a}} \pm 0.89$ & $7.00^{\mathrm{a}} \pm 0.90$ & $7.50^{\mathrm{a}} \pm 0.97$ \\
\hline P. pentosaceus & $19.05^{\mathrm{a}} \pm 2.46$ & $21.00^{\mathrm{a}} \pm 2.71$ & $23.65^{\mathrm{a}} \pm 3.05$ & $26.65^{\mathrm{a}} \pm 3.44$ & $30.10^{\mathrm{a}} \pm 3.89$ & $30.00^{\mathrm{a}} \pm 3.87$ & $32.25^{\mathrm{a}} \pm 4.16$ \\
\hline
\end{tabular}

Note: ${ }^{\mathrm{a}-\mathrm{g}}$ Means with different superscripts within row are significantly different $(P<0.05)$. 
resistant $(\mathrm{P}<0.05)$ against nalidixic acid, gentamycin, ciprofloxacin, sulphamethoxazole, kanamycin, streptomycin and vancomycin. However, Sieo et al. [28] claimed that $L$. acidophilus isolated from chicken gastrointestinal tract was resistant to $100 \%$ chloramphenicol $(\geq 200 \mu \mathrm{g} / \mathrm{ml})$, $58 \%$ to erythromycin $(\geq 200 \mu \mathrm{g} / \mathrm{ml})$ and $17 \%$ to tetracycline $(\geq 200 \mu \mathrm{g} / \mathrm{ml})$. L. brevis and L. curvatus had similar trend of resistance against the antibiotics. However, $L$. brevis was more resistant to ciprofloxacin (a fluoroquinolone), tetracycline, and vancomycin as found in the study of Fukao et al. [29]. L. delbrueckii subsp delbrueckii, L. fermentum, L. rhaminosus, L. salivarious, Leu. mesenteroides, $P$. damnosus, $P$. pentosaceus were sensitive to all the tested antibiotics.

According to Ouoba et al. [30], L. acidophilus L. fermentum, and L. rhaminosus contained positive amplicons of resistance genes encoding aminoglycoside (aph (3')-III, $\operatorname{aadA}, \operatorname{aadE})$ and tetracycline tet (S), and hence they had higher prevalence of phenotypic resistance for aminoglycoside. This can be attributed to intrinsic resistance of different species since none of these bacteria were resistant to penicillin (first generation $\beta$ - lactam). These organisms have the potential to act as reservoir of antimicrobial resistant genes and which have potential to be transferred to other bacteria. Moreover, intrinsic resistance to vancomycin was confirmed for $L$. paracasei, L. salivarius and L. plantarum, and L. salivarius was also typically resistant to erythromycin [31]. In other study, L. salivarius had the highest resistance to kanamycin and neomycin, but demonstrated the lowest resistance to penicillin [32]. L. paracasei subsp paracasei was usually used as probiotic in lactic acid fermented food for human consumption [33].

Vankerckhoven et al. [34] reported that L. paracasei 8700:2 strain was not resistant to antibiotic. However, $L$. paracasei subsp paracase $i$ was found to be more resistant against nalidixic acid and sulphamethozole as compared to other antibiotics as found in this study. Furthermore, $L$. plantarum was sensitive to all the tested antibiotics except nalidixic acid, gentamycin, sulphamethoxazole, kanamycin and streptomycin. In contrast, Toomey et al. [35] claimed that L. plantarum harbored erm (B) and msrA/B genes, and tet $(\mathrm{M})$ gene that resistant to erythromycin and tetracycline, respectively. Additionally, it is also intrinsically resistant to vancomycin. Similar trend was also found in $L c$. lactis except for sulphamethoxazole in current study. Tetracycline and erythromycin-resistance genes were found in Lc. lactis and this microbe is normally representing the fermenting microflora of typical Italian traditional cheese Mozzarella di Bufala Campana [36]. It has been reported that L. fermentum 1, Lc. lactic subsp. lactic 1, L. paracasei subsp. paracasei 1, L. rhamnosus and Lc. lactic subsp. lactic 2 isolated from raw poultry meat were resistant to polymycin B (PB 100), trimethoprim (TM 5), tetracycline (TE 30), oxacillin (OX 1), kanamycin (K 30), erythromycin (E 15), gentamycin (CN 10), ciprofloxacin (CIP 5) and cephalothin (CL 30) [37].

\section{Conclusions}

In conclusions, many species of LAB were found in the faecal samples of broiler chicken. Each species of LAB has different inhibitory zone related to antibiotic susceptibility. These results indicate that LAB may develop resistance against antibiotic that may result from the horizontal transferring of resistant gene to other microflora in the gut. The development of resistance to antibiotic can be attributed to long term usage of antibiotic as therapeutics and growth promoter. Thus, it is important and essential to advise the farmer a proper way of antibiotic use as therapeutic and growth promoter agents. Additionally, supplementation of unknown source of probiotic as feed additive needs to be monitored closely in animal feeding.

\section{Competing interests}

The authors declare that they have no competing interests.

\section{Authors' contributions}

NS and DWC conceived the idea and carried out the antibiotic resistance studies and initial analyses on collected data. NS has drafted the manuscript. HLF involved in experimental design, data acquisition, analyses and interpretation and revising the manuscript. TCL involved in conceptual the experimental design, data acquisition, analyses and interpretation of data, and revising the manuscript. RAR involved in acquisition of data and revising the manuscript. All authors read and approved the manuscript.

\section{Acknowledgement}

This project was supported by Long-Term Research Grant Scheme (LRGS) from Ministry of Education Malaysia.

\section{Author details}

${ }^{1}$ Department of Animal Science, Faculty of Agriculture, Universiti Putra Malaysia, 43400, UPM Serdang Selangor, Malaysia. ${ }^{2}$ Department of Bioprocess Technology, Faculty of Biotechnology and Biomolecular Sciences, Universiti Putra Malaysia, 43400, UPM Serdang Selangor, Malaysia. ${ }^{3}$ Department of Cell and Molecular Biology, Faculty of Biotechnology and Biomolecular Sciences, Universiti Putra Malaysia, 43400, UPM Serdang Selangor, Malaysia. ${ }^{4}$ Institute of Bioscience, Universiti Putra Malaysia, 43400, UPM Serdang Selangor, Malaysia. ${ }^{5}$ Institute of Tropical Agriculture, Universiti Putra Malaysia, 43400, UPM Serdang Selangor, Malaysia.

Received: 25 September 2013 Accepted: 15 January 2014 Published: 22 January 2014

\section{References}

1. Madden D: Antibiotic resistance in Escherichia coli A practical investigation of bacteria conjugation. National Centre for Biotechnology Education (NCBE): the University of Reading 2009.

2. WHO ISDA: Antimicrobial resistance Bad bug, no drugs as antibiotic discovery stagnates a public health crisis advance a review. Official journal of the Australian Society for Microbiology Inc 2007, 28:152.

3. Scott KP: The role of conjugative transposons in spreading antibiotic resistance between bacteria that inhabit the gastrointestinal tract. Cell Mol Life Sci 2002, 59:2071-2082.

4. Schjørring S, Krogfelt KA: Assessment of bacterial antibiotic resistance transfers in the gut. Int J Microbiol 2011. doi:10.1155/2011/312956.

5. Loh TC, Lee TM, Foo HL, Law FL, Rajion MA: Effects on growth performance, faecalmicroflora and plasma cholesterol after supplementation of spray-dried metabolite to postweaning rats. Czech J Anim Sci 2008, 54:10-16. 
6. Loh TC, Chong SW, Foo HL, Law FL: Growth performance and fecal microflora of rats offered metabolites from lactic acid bacteria. J Appl Anim Res 2009, 34:61-64.

7. Thanh NT, Loh TC, Foo HL, Hair-Bejo M, Azhar BK: Effects of feeding metabolite combinations produced by Lactobacillus plantarumon growth performance, faecal microbial population, small intestine villus height and faecal volatile fatty acids in broilers. Br Poult Sci 2009, 50:298-306.

8. Loh TC, Thanh NT, Foo HL, Hair-Bejo M, Azhar BK: Feeding of different levels of metabolite combinations produced byLactobacillus plantarumon growth performance, faecalmicroflora, volatile fatty acids and villi height in broilers. Anim Sci J 2010, 81:205-214.

9. Choe DW, Loh TC, Foo HL, Hair-Bejo M, Awis QS: Egg production, faecal $\mathrm{pH}$ and microbial population, small intestine morphology, and plasma and yolk cholesterol in laying hens given liquid metabolites produced by Lactobacillus plantarum strains. Br Poult Sci 2012, 53:106-115.

10. Thu TV, Loh TC, Foo HL, Yaakub H, Hair-Bejo M: Effects of liquid metabolite combinations produced byLactobacillus plantarumon growth performance, faeces characteristics, intestinal morphology and diarrhoea incidence in postweaning piglets. Trop Anim Health Prod 2011, 43:69-75.

11. Gueimonde M, Sánchez B, de Los Reyes-Gavilán CG, Margolles A: Antibiotic resistance in probiotic bacteria. Front Microbiol 2013, 4:202. doi:10.3389/ fmicb.2013.00202.

12. Egervärn $M$, Roos S, Lindmark H: Identification and characterization of antibiotic resistance genes in Lactobacillus reuteri and Lactobacillus plantarum. J Appl Microbiol 2009, 17:1658-1668.

13. Hamilton-miller JMT, Shah S: Vancomycin susceptibility as an aid to the identification of lactobacilli. Let App/Microbiol 1998, 26:153-154.

14. Danielsen M, Wind A: Susceptibility of Lactobacillus spp. to antimicrobia agents. Int J Food Microbiol 2003, 82:1-11.

15. Ammor MS, Flórez AB, Van Hoek AHAM, de Los Reyes-Gavilán CG, Aarts HJM Margolles A, Mayo B: Molecular characterization of intrinsic and acquired antibiotic resistance in lactic acid bacteria and bifidobacteria. J Mol Microbiol Biotechnol 2008, 14:6-15.

16. Korhonen JM, Danielsen M, Mayo B, Egervarn H, Axelsson L, Huys G: Antimicrobial susceptibility and proposed microbiological cut-off values of lactobacilli by phenotypic determination. Int J Probiot Prebiot 2008, 3:257-268.

17. Mayrhofer S, van Hoeck AHAM, Mair C, Huys G, Arts HJM, Kneifel W: Antibiotic susceptibility of members of the Lactobacillus acidophilus group using broth microdilution and molecular identification of their resistance determinants. Int J Food Microbiol 2010, 144:81-87.

18. Foo HL, Loh TC, Law FL, Lim YZ, Kufli CN, Gulam R: Effects of feeding Lactobacillus plantarum I-UL4 isolated from Malaysian Tempeh on growth performance, faecal flora and lactic acid bacteria and plasma cholesterol concentrations in postweaning rats. Food Sci Biotechnol 2003, 4:403-408.

19. Foo HL, Loh TC, Lim YS, Syukriyah MH, Kufli CN, Law FL: Effect of fermented fruits on growth performance, shedding of Enterobacteriacea and Lactic Acid Bacteria and plasma cholesterol on rats. Pakistan J Nut 2003, 2:228-233.

20. Bauer AW, Kirby WMM, Sherris JC, Turck M: Antibiotic susceptibility testing by a standardized single disk method. Am J Clin Pathol 1966, 45:493-496.

21. SAS Institute: SAS/STAT User's Guide, Version 6. 5th edition. Cary, NC: SAS Institute Inc; 1999.

22. Hilmi HTA, Surakka A, Apajalahti J, Saris PEJ: Identification of the most abundant Lactobacillus species in the crop of 1- and 5-week-old broiler chickens. Appl Environ Microbiol 2007, 73:67-73.

23. Kaktcham PM, Zambou NF, Tchouanguep FM, El-Soda M, Choudhary MI: Antimicrobial and safety properties of lactobacilli isolated from two Cameroonian traditional fermented foods. Sci Pharm 2012, 80:189-203.

24. Lavanya B, Sowmiya S, Balaji S, Muthuvelan B: Screening and characterization of lactic acid bacteria from fermented milk. Br J D Sci 2011, 2:5-10.

25. Tyler LH, Roberta JW, Christian M: Potent small molecule suppression of oxacillin resistance in methicillin resistant Staphylococcus aureus. Angew Chem Int Ed 2012, 51:11254-11257.

26. Gilchrist MJ, Greko C, Wallinga DB, Beran GW, Riley DG, Thorne PS: The potential role of concentrated animal feeding operations in infectious disease epidemics and antibiotic resistance. Environ Health Perspect 2007, 115:313-316.

27. Bassam YK: Leuconostoc mesenteroides cause Nosocomial UTI at a tertiary care center in North India. J Thi-Qar Univer 2011, 4:23-34.
28. Sieo CC, Norhani A, Tan WS, Ho YW: Plasmid profiling and curing of Lactobacillus strains isolated from the gastrointestinal tract of chicken. J Microbiol 2005, 43:251-256.

29. Fukao M, Tomita H, Yakabe T, Nomura T, Ike Y, Yajima N: Assessment of antibiotic resistance in probiotic strain Lactobacillus brevis KB290. J Food Protect 2009, 72:1923-1929.

30. Ouoba LII, Lei V, Jensen LB: Resistance of potential probiotic lactic acid bacteria and bifidobacteria of African and European origin to antimicrobials: Determination and transferability of the resistance genes to other bacteria. Int J Food Microbiol 2008, 121:217-224.

31. Blandino G, Milazzo I, Fazio D: Antibiotic susceptibility of bacterial isolates from probiotic products available in Italy. Microbial Ecolo Health Dis 2008, 20:199-203.

32. Majhenič AC, Matijašič BB: Antibiotics influence on lactic acid bacteria inhabiting gastrointestinal tract. Mljekarstvo 2001, 51:119-134.

33. Sigrid M, Angela HAM, Christiane M, Geert H, Henk JM, Wolfgang K, Konrad JD: Antibiotic susceptibility of members of the Lactobacillus acidophilus group using broth micro dilution and molecular identification of their resistance determinants. Int J Food Microbiol 2010, 144:81-87.

34. Vankerckhoven V, Geert HH, Vancanneytc M, Klared CVI, Romonde MB, Entenzaf JM, Moreillonf P, Windg RD, Knolg J, Wiertzh E, Poti B, Vaughanj EE, Kahlmeterl KG, Gossensa H: Biosafety assessment of probiotics used for human consumption: recommendations from the EU-PROSAFE project. Tren Food Sci Technol 2008, 19:102-114.

35. Toomey N, Bolton D, Fanning S: Characterization and transferability of antibiotic resistance genes from lactic acid bacteria isolated from Irish pork and beef abattoirs. Res Microbiol 2010, 161:127-135.

36. Devirgiliis C, Barile S, Caravelli A, Coppola D, Perozzi G: Identification of tetracycline and erythromycin resistant Gram- positive cocci within the fermenting microflora of an Italian dairy food product. J Appl Microbiol 2010, 109:313-323.

37. Lengkey HAW, Balia RL, Togoe I, Taşbac BA, Ludong M: Isolation and identification of lactic acid bacteria from raw poultry meat. Biotechnol Anim Hus 2009, 25:1071-1077.

doi:10.1186/1757-4749-6-1

Cite this article as: Shazali et al:: Prevalence of antibiotic resistance in lactic acid bacteria isolated from the faeces of broiler chicken in Malaysia. Gut Pathogens 2014 6:1.

\section{Submit your next manuscript to BioMed Central and take full advantage of:}

- Convenient online submission

- Thorough peer review

- No space constraints or color figure charges

- Immediate publication on acceptance

- Inclusion in PubMed, CAS, Scopus and Google Scholar

- Research which is freely available for redistribution 